\section{The Growth of Clostridium pasteurianum in Synthetic Nutrient Solution}

ARTTURI I. VIRTANEN and SINIKEA LUNDBOM

Laboratory of the Foundation for Chemical Research, Biochemical Institute, Helsinki, Finland

V arious experiments have been made with anaerobic Clostridia which fix molecular nitrogen. Until now, nutrient solutions to which potato extract has been added have generally been used, as the bacterium could not be made to grow successfully with synthetic nutrients. This has made it more difficult to obtain reliable results in such experiments as investigation of secretion of nitrogen compounds, or determination of the requirements of Mo or other trace elements, as many unknown factors are included in potato extract. In a recent paper ${ }^{1}$ on the inhibition by $\mathrm{N}_{2} \mathrm{O}$ of biological nitrogen fixation and the uptake of combined nitrogen we mentioned that we have been able to make Clostridium pasteurianum grow in synthetic nutrient solution by adding different vitamins to the solution. In this paper we will give a detailed account of the vitamin requirements of Clostridium.

The bacterial strain, $C l$. pasteurianum W5, used in our experiments was kindly provided by Dr. H. L. Jensen, Lyngby, Denmark.

Basal nutrient solution: $0.5 \mathrm{~g} \mathrm{~K}, \mathrm{HPO}_{4}$, $0.5 \mathrm{~g} \mathrm{KH}_{2} \mathrm{PO}_{4}, 0.1 \mathrm{~g} \mathrm{NaCl}, 10 \mathrm{mg} \mathrm{FeSO} \cdot 7$ $\mathrm{H}_{2} \mathrm{O}, 25.2 \mathrm{mg} \mathrm{Na} \mathrm{MO}_{4} \cdot 2 \mathrm{H}_{2} \mathrm{O}, 20 \mathrm{~g}$ glucose, $1000 \mathrm{ml}$ distilled water. The nutrient solution had to be clarified by filtration as the growth was determined by turbidity measurements. The solution without sugar was sterilized in an autoclave for $20 \mathrm{~min}$ at $120^{\circ} \mathrm{C}$.

Glucose and vitamins were added to a sterile mineral salt solution, which was then poured into test-tubes, $10 \mathrm{ml}$ in each. The test-tubes were sterilized for $15 \mathrm{~min}$ at $115^{\circ} \mathrm{C}$. The $\mathrm{pH}$ was regulated so that it should be 7.4 in the tubes before inocula. tion. Bacteria for inoculation were grown in 1 Erlenmayer flasks in a water-bath at $30^{\circ} \mathrm{C}$. Air was displaced from the flasks with nitrogen gas (washed with sulphuric acid and alkaline pyrogallol solution). The nutrient solution contained all the 8 vitamins which will be mentioned below.
From this culture $10 \mathrm{ml}$ were inoculated into $500 \mathrm{ml}$ nutrient solution without any addition of vitemins. With the inoculation was added such an amount of vitamins that the bacteria grew fairly well. The cultivation took place under the same conditions as the earlier one.

From this cultivation $1 \mathrm{ml}$ was inoculated into each of the $10 \mathrm{ml}$ testsolutions in tubes. The test-tubes were placed in a 121 vacuum desiccator from which air was removed with a suction-pump. The desiccator was then filled with nitrogen gas and alkaline pyrogallol solution placed on the bottom of the desiccator. The nitrogen procedure was then repeated three times. Growth temperature was $30^{\circ} \mathrm{C}$, growth period 7 days.

Vitamins used: 1. Folic acid, 2. Ca-pantothenate, 3. Pyridoxin, 4. p-Aminobenzoic acid, 5. Riboflevine, 6. Thiamine, 7. Niacin, 8. Biotin.

Vitamins used in different experiments can be seen in Table 1. After 7 days of growth, $1 \mathrm{ml}$ was transferred from each experiment to a new nutrient solution of the same kind. In this way the vitamins which had been added with the inoculation were gradually excluded.

Measuring of the growth. In each experiment there were 5 parallel test-tubes. In 4 of them growth was measured with the Klett-Summerson photometer, filter 42 , and the 5 th tube used for inoculation into the following 5 tubes containing sterile nutrient solution.

The inoculation was continued until growth had ceased in all 5 test-tubes, when the experiment was finished. After 7 inoculations even those experiments in which the bacteria still grew were discontinued. In these cases the total period of growth comprised 7 weeks. Experiments 6 and $1+2$ were inadvertently finished after 5 weeks, although the bacteria were still growing.

The figures in Table 1 show photometer readings. The readings are mean values from the readings of 4 tubes. $0=$ no growth.

The results of the experiments indicate: Only folic acid has maintained even growth after all the 7 inoculations.

Thiamine has maintained growth after 5 inoculations. The experiment was then inadvertently finished. Since the mixture of riboflavine, thiamine, niacin, and biotin has not been able to maintain growth after the 4th inoculation, thiamine obviously cannot maintain growth alone. 
Table 1. Vitamin requirements of Clostridium pasteurianum.

\begin{tabular}{|c|c|c|c|c|c|c|c|}
\hline $\begin{array}{l}\text { Vitamins added to } \\
\text { the basal nutrient } \\
\text { solution }\end{array}$ & $\begin{array}{l}\text { 1. inocu. } \\
\text { lation }\end{array}$ & $\begin{array}{l}\text { 2. inocu- } \\
\text { lation }\end{array}$ & $\begin{array}{c}\text { 3. inocu- } \\
\text { lation }\end{array}$ & $\begin{array}{l}\text { 4. inocu- } \\
\text { lation }\end{array}$ & $\begin{array}{l}\text { 5. inocu- } \\
\text { lation }\end{array}$ & $\begin{array}{l}\text { 6. inocu- } \\
\text { lation }\end{array}$ & $\begin{array}{l}\text { 7. inocu- } \\
\text { lation }\end{array}$ \\
\hline 1. Folic acid & 64 & 111 & 156 & 161 & 121 & 122 & 104 \\
\hline $\begin{array}{l}\text { 2. Ca-pantothen- } \\
\text { ate }\end{array}$ & 101 & 100 & 116 & 58 & 0 & 0 & $\mathbf{0}$ \\
\hline 3. Pyridoxin & 66 & 79 & 150 & 125 & 107 & 69 & $\mathbf{0}$ \\
\hline $\begin{array}{l}\text { 4. } p \text {-Aminoben- } \\
\text { zoic acid }\end{array}$ & 72 & $\mathbf{0}$ & $\mathbf{0}$ & 0 & 0 & $\mathbf{0}$ & $\mathbf{0}$ \\
\hline 5. Riboflavine & 132 & 74 & $\mathbf{0}$ & $\mathbf{0}$ & $\mathbf{0}$ & $\mathbf{0}$ & $\mathbf{0}$ \\
\hline 6. Thiamine & 110 & 51 & 122 & 104 & 111 & finished & \\
\hline 7. Niacin & 62 & $\mathbf{0}$ & 0 & $\mathbf{0}$ & $\mathbf{0}$ & $\mathbf{0}$ & $\mathbf{0}$ \\
\hline 8. Biotin & 61 & $\mathbf{0}$ & 0 & $\mathbf{0}$ & $\mathbf{0}$ & $\mathbf{0}$ & 0 \\
\hline $\begin{array}{l}\text { Combinations: } \\
1+2\end{array}$ & 110 & 135 & 181 & 187 & 121 & finished & . \\
\hline $3+4$ & 80 & 68 & 72 & $\mathbf{0}$ & $\mathbf{0}$ & 0 & 0 \\
\hline $5+6$ & 119 & $\mathbf{0}$ & $\mathbf{0}$ & $\mathbf{0}$ & $\mathbf{0}$ & 0 & $\mathbf{0}$ \\
\hline $7+8$ & 68 & 0 & 0 & 0 & 0 & 0 & 0 \\
\hline $1+2+3+4$ & 102 & 130 & 163 & 144 & 124 & 135 & 115 \\
\hline $5+6+7+8$ & 112 & 102 & 115 & 0 & $\mathbf{0}$ & 0 & 0 \\
\hline $\mid \begin{array}{r}1+2+3+4+ \\
5+6+7+8\end{array}$ & 108 & 116 & 118 & 118 & 118 & 148 & 131 \\
\hline
\end{tabular}

$4 \mathrm{mg}$ of each of the vitamins $1,2,3$, and 4 , and $20 \mathrm{mg}$ of each of the vitamins 5,6 , and 7 , and $10 \mu \mathrm{g}$ of vitamin 8 , were weighed in volumetric flasks and diluted to $100 \mathrm{ml}, 20 \mathrm{ml}$ of this solution were put in 11 nutrient solution.

In nutrient solutions containing $p$ aminobenzoic acid, riboflavine, niacin, and biotin growth has not occurred after the 2nd or 3rd inoculation.

Pantothenic acid and pyridoxin have not been able to maintain growth after the 5th and 6th resp. inoculations.

The experiments with mixtures of vitamins have given results which conform with those obtained with separate vitamins. Only mixtures containing folic acid have maintained even growth during the whole experiments $(1+2,1+2+3+4$, and
$1+2+3+4+5+6+7+8 ; \quad$ the first one was indeed finished inadvertently after the 5th inoculation, but judging by experiment 1 growth would have been obvious even after this).

On the basis of our experiments folic acid is a decisive factor for the growth of Clostridium pasteurianum

1. Virtanen, A. I. and Lundbom, S. Acta Chem. Scand. 7 (1953) 1223.

Received May 14, 1954.

Acta Chem. Scand. 8 (1954) No. 5 